\title{
Heat Shocks Reduce Chilling Sensitivity of Cotton, Kenaf, Okra, and Rice Seedling Radicles
}

\author{
Mary E. Mangrich and Mikal E. Saltveit \\ Mann Laboratory, Department of Vegetable Crops, University of California, One Shields Ave., Davis, CA \\ 95616-8631
}

\begin{abstract}
AdDITIONAL INDEX wORDs. Gossypium hirsutum, heat-shock proteins, Hibiscus cannabinus, Hibiscus esculentus, Abelmoschus esculentus, radicle elongation, Oryza sativa, Triticum sativum
\end{abstract}

\begin{abstract}
Seeds of cotton (Gossypium hirsutum L.), kenaf (Hibiscus cannabinus L.), okra [Abelmoschus esculentus (L.) Moench. 'Clemson Spineless' (syn. Hibiscus esculentus L.)], rice (Oryza sativa L.), and wheat (Triticum sativum (L.) Lam.) were germinated and grown at $25{ }^{\circ} \mathrm{C}$ until their radicles reached $10 \mathrm{~mm}$ in length. They were then exposed to chilling temperatures for 0 to 5 days followed by 3 days at $25^{\circ} \mathrm{C}$. Radicle length was measured periodically and inhibition of elongation was used as an indicator of the severity of chilling injury. Exposure to chilling reduced radicle elongation in all species except chilling insensitive wheat. When seedlings were heat-shocked at $45^{\circ} \mathrm{C}$ for 1 to 12 min before being chilled, radicles of the chilling sensitive okra, kenaf, cotton, and rice seedlings elongated more than seedlings not heatshocked before chilling. The method of heat-shock application and the stringency (i.e., time $\times$ temperature) of the heatshock and chilling treatments all affected the response of the tissue. In comparison to nonheat-shocked wheat seedlings, the radicles of chilling insensitive wheat seedlings did not elongate more than seedlings in which the heat shocks were applied before chilling. A brief heat shock ameliorates chilling injury in these chilling sensitive species.
\end{abstract}

Chilling injury has been defined as damage sustained by plant tissue subjected to nonfreezing temperatures below $\approx 12^{\circ} \mathrm{C}$ (Lyons, 1973; Saltveit and Morris, 1990). Plants of tropical and subtropical origin are usually sensitive to chilling injury, with the degree of sensitivity and symptoms expressed variable among tissues and species. Symptoms of chilling injury include stunted growth, internal and external discoloration, development of waterlogged or necrotic areas, and abnormal ripening of fruit (Lyons, 1973). At the cellular level, effects include cessation of cytoplasmic streaming, loss of membrane fluidity, changes in enzyme activity, accumulation of substrates and other metabolic changes (Saltveit and Morris, 1990). While many temperature-induced changes have been suggested as the primary cause of chilling injury, membrane damage has most often been proposed as the initial step in the development of chilling injury (Lyons and Raison, 1970; Nishida and Murata, 1996; Saltveit, 1999).

Many methods have been developed to alleviate or prevent chilling injury (Saltveit and Morris, 1990). These methods include: temperature conditioning, application of specific chemical formulations before chilling, intermittent warming, use of controlled atmospheres during chilling, storage at high relative humidity, and rapid use of the injured produce after chilling. Exposure to specific temperature regimes before chilling (i.e., temperature conditioning) can significantly alter the tissue's subsequent chilling sensitivity (Saltveit and Morris, 1990). Conditioning is usually used to increase chilling tolerance, but it can also increase chilling sensitivity. Chilling sensitivity was increased in tomato (Lycopersicon esculentum Mill.) fruit tissue when held for $6 \mathrm{~h}$ at temperatures from 15 to $32^{\circ} \mathrm{C}$ before chilling (Saltveit, 1991; Saltveit and Cabrera, 1987). In contrast, the tissue became more chilling tolerant when held at temperatures $>34^{\circ} \mathrm{C}$ (Saltveit, 1991). These higher temperature are within the range that induces the synthesis of heat-shock proteins (Vierling, 1990).

When subjected to temperatures $\approx 10$ to $15^{\circ} \mathrm{C}$ above the

Received for publication 26 July 1999. Accepted for publication 29 Dec. 1999. We thank Brian S. Baldwin of Mississippi State University for the gift of 'Everglades 41' kenaf seeds. The cost of publishing this paper was defrayed in part by the payment of page charges. Under postal regulations, this paper therefore must be hereby marked advertisement solely to indicate this fact. optimal growing temperature, organisms selectively produce proteins (i.e., heat-shock proteins; hsps) that appear coincident with tolerance to subsequent high temperatures that would have been lethal (Vierling, 1990). Heat shock induction of chilling tolerance has been correlated with the appearance and disappearance of these induced proteins (Collins et al., 1995; Sabehat et al., 1996). Heat shocks alleviate chilling injury symptoms in mung bean [(Vignaradiata (L.)R.Wilcz.(syn.Phaseolus aureus Roxb.)] seedlings (Collins et al., 1993) and cucumber (Cucumis sativus L. 'Poinsett 76') seedlings (Jennings and Saltveit, 1994). Heat shocks also alleviate chilling-induced reductions in radical elongation in corn (Zea mays L.), mung bean and tomato seedlings, but had no discernable effect in okra [Abelmoschus esculentus 'Clemson Spineless' (syn. Hibiscus esculentus L.)] (Rab and Saltveit, 1996). Other abiotic shocks that are known to induce hsps (Vierling, 1990) were also effective in protecting the radicles of cucumber seedlings against chilling injury (Jennings and Saltveit, 1994).

This study was undertaken to study the ability of a heat shock to induce chilling tolerance in three malvaceous species [i.e., cotton (Gossypium hirsutum), kenaf (Hibiscus cannabinus), and okra and to determine if there is a common response to heat shock among crops in this family. The response of two monocotyledonous species [chilling sensitive rice (Oryza sativa) and chilling tolerant wheat (Triticum sativum)] to heat shock and chilling was also investigated.

\section{Materials and Methods}

Plant material. Seeds of 'Clemson Spineless' okra, 'GC702' cotton, 'M202' rice, and 'Yecoro Rojo' wheat were obtained from local sources. Seeds of 'Everglades 41' kenaf were a gift from Brian S. Baldwin of Mississippi State Univ. Seeds were imbibed in aerated water overnight at $18^{\circ} \mathrm{C}$ in the dark. They were then placed on moist paper towels overlaying capillary cloth in the light, and sandwiched between $15 \times 30-\mathrm{cm}$ Plexiglas plates $(3$ $\mathrm{mm}$ thick). The plates were placed vertically in ethylene-free air at $25^{\circ} \mathrm{C}$ until the radicles grew to a length of $10 \pm 1 \mathrm{~mm}$.

Chilling treatments. Selected seedlings were placed on 
moist, paper towel-covered capillary cloths between $13 \times 7$-mm Plexiglas plates. These sandwiches were placed at $2.5^{\circ} \mathrm{C}$ in the dark for 1 to $7 \mathrm{~d}$, after which they were moved to $25^{\circ} \mathrm{C}$ for $72 \mathrm{~h}$. Rice was also chilled at $4.5^{\circ} \mathrm{C}$. Radical length was measured periodically through the clear Plexiglas with a metric ruler to the nearest millimeter, and at the end of the experiment by removing the Plexiglas plate. The effect of chilling is reported as either radicle elongation during the $72 \mathrm{~h}$ at $25^{\circ} \mathrm{C}$, or as inhibition of elongation compared to the nonchilled control during this period. In some analyses, radicle elongation after chilling of individual seeds in each treatment was ranked from longest to shortest to compare the variable responses of individual seedlings among the treatments.

Heat SHock treatments. Heat treatments were applied in most cases by placing the seedlings on moist filter paper in plastic petri dishes which were then floated in the light for 1-12 min on the surface of water in a controlled temperature bath. At the conclusion of the treatment the petri dishes were floated on the surface of water at room temperature $\left(\approx 21{ }^{\circ} \mathrm{C}\right)$ for $5 \mathrm{~min}$ to cool. Seedlings were then transferred to Plexiglas sandwiches and remained at $21^{\circ} \mathrm{C}$ for $2 \mathrm{~h}$, after which the plates were placed at chilling (i.e., 2.5 or $4.5^{\circ} \mathrm{C}$ ) or growth $\left(25^{\circ} \mathrm{C}\right)$ temperatures.

In some cases, seedlings were placed in plastic tea strainers that allowed water to flow amongst the seeds. The strainers were placed directly in the water bath. After 60 to $720 \mathrm{~s}$, the strainers were immersed in room temperature water to cool the seeds. Seeds were then transferred to Plexiglas plate sandwiches and placed at the chilling or growth temperatures as described previously.

Statistical DESign AND ANALysis. All experiments were repeated at least once with similar results. Each experimental treatment had at least three replicates (plates) with 7 to 10 seedlings per plate. Means and standard deviations were calculated from the data, and some experimental results were subjected to analysis of variance from which LSD values were calculated.

\section{Results}

\section{Effect of chilling on subsequent radicle elongation}

ОкRA. As little as $1 \mathrm{~d}$ of chilling at $2.5^{\circ} \mathrm{C}$ inhibited elongation of okra radicles (Fig. 1). The greatest inhibition occurred after $1 \mathrm{~d}$, with a $47 \%$ decrease in elongation subsequent to chilling compared to the nonchilled controls, while $2 \mathrm{~d}$ of chilling resulted in an additional $30 \%$ decrease in elongation compared to $1 \mathrm{~d}$ of chilling. Little change was seen in radicle elongation after $2 \mathrm{~d}$ of chilling. Ranking radicle elongation of the individual seedlings shows that the seedlings chilled for $1 \mathrm{~d}$ have a wide range of responses (Fig. 2). The patterns for days 2 through 5 had similar patterns with little variation for the majority of the seeds.

Cotron. After $1 \mathrm{~d}$ of chilling at $2.5^{\circ} \mathrm{C}$, cotton radicles exhibited a reduction in subsequent elongation at $25{ }^{\circ} \mathrm{C}$ of $23 \%$ compared to the nonchilled controls (Fig. 1). The greatest reduction occurred between the first and second days of chilling, where elongation decreased by $77 \%$. After the second day of chilling, elongation was minimal and by the fourth day no elongation was observed.

KEnAF. Three days of chilling at $2.5^{\circ} \mathrm{C}$ were needed to cause a significant $67 \%$ reduction in elongation of kenaf radicles compared to the nonchilled controls (Fig. 1). Radicle elongation was minimal in seedlings chilled for $4 \mathrm{~d}$ or more.

RICE. Response of rice to chilling was very severe and immediate (Fig. 3). Chilling at $2.5^{\circ} \mathrm{C}$ for $1 \mathrm{~d}$ resulted in a $95 \%$ reduction in subsequent elongation compared to the nonchilled controls. Additional days of chilling resulted in death of nearly all the seedlings. Variation among replicates chilled for any length of time was minimal at this chilling temperature. When chilled at 4.5 ${ }^{\circ} \mathrm{C}$, subsequent radicle elongation was halved by each day of chilling, so that elongation was reduced $77 \%$ after $2 \mathrm{~d}$ of chilling. Elongation was marginal after $3 \mathrm{~d}$ of chilling at $4.5^{\circ} \mathrm{C}$.

WheAT. No significant differences in elongation after chilling were observed among wheat radicles chilled for 1 to $5 \mathrm{~d}$ at $2.5^{\circ} \mathrm{C}$ (Fig. 3).

\section{Effect of heat shock treatments on chilling response}

OKRA. Heat-shock treatments caused only minor changes in the elongation of nonchilled seedling radicles when administered by floatation (range $=55$ to 41 ; average $\pm S D=50 \pm 2.8 \mathrm{~mm}$ ). However, the same duration of heat-shock treatment administered by immersion had a significant negative effect on subsequent elongation of nonchilled radicles (range 54 to 14; average $\pm \mathrm{SD}=25 \pm 8.8 \mathrm{~mm}$ ). When chilled seedlings were compared to nonchilled seedlings having the same heat-shock treatment by flotation, percent inhibition caused by $3 \mathrm{~d}$ of chilling at $2.5^{\circ} \mathrm{C}$ declined in a roughly linear fashion with time of heat-shock treatment; percent inhibition $=95-(7.06 \times$ min of heat shock $)$, with an $R^{2}$ of 0.98 (Fig. 4). In contrast, there were differences in the calculated percent inhibition if the chilled, heat-shock treatments were compared to the nonchilled and nonheat-shocked controls. Although the 4 and 8 min heat-shock treatments gave similar results as before when compared to their respective nonchilled, heat-shock-treated controls, the 12 min heat-shock

Fig. 1. Chilling at $2.5{ }^{\circ} \mathrm{C}$ for 0 to $5 \mathrm{~d}$ on the subsequent radicle elongation of germinated cotton, kenaf, and okra seedlings at $25^{\circ} \mathrm{C}$. Seedlings initially had 10 \pm 1 -mm-long radicles. Vertical bars represent SE $(n=17)$.

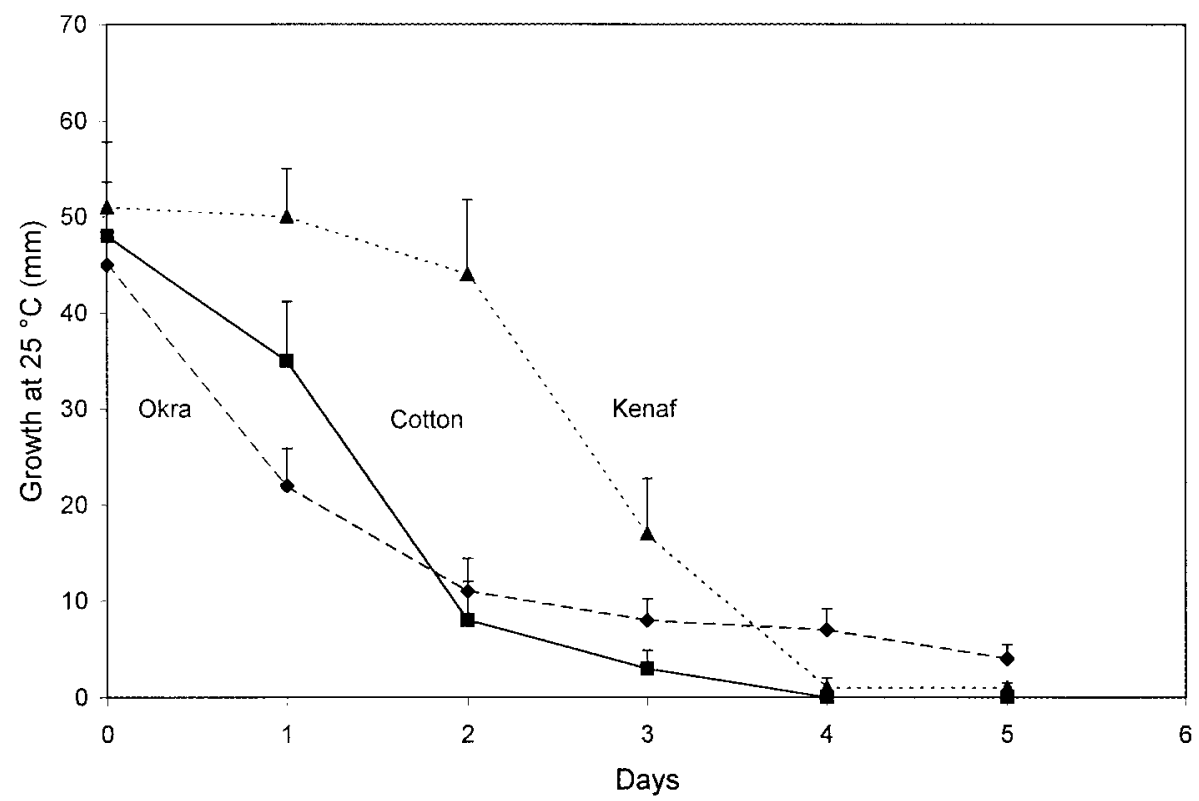




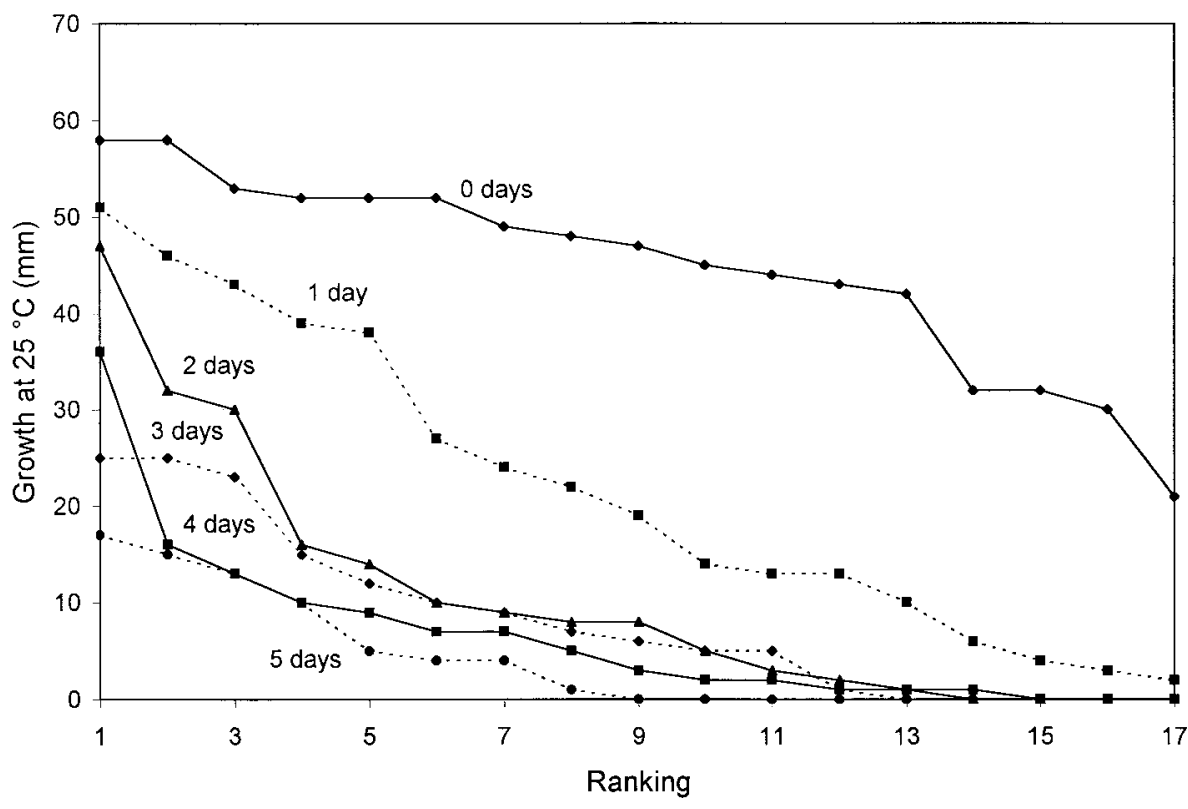

kenaf seeds before chilling resulted in increased elongation after chilling (Fig. 4). Elongation was not improved with 8 and 12 min heat-shock treatments compared to the nonheat-shock-treated, chilled controls, and 12 minute heat-shock treatments resulted in decreased elongation compared to the controls. Nonchilled controls exhibited a significant decrease in elongation with $8 \mathrm{~min}$ of heat shock treatment (data not presented).

RICE. Rice seedlings with radicles 10 $\mathrm{mm}$ long did not exhibit increased chilling tolerance after being subjected to $45^{\circ} \mathrm{C}$ heat shock treatments of 2 to $8 \mathrm{~min}$ and then chilled at $2.5^{\circ} \mathrm{C}$ for $3 \mathrm{~d}$ (data not presented). However, when the severity of the chilling exposure was reduced by holding the seedlings at $4.5^{\circ} \mathrm{C}$ for $2 \mathrm{~d}$, heat shock treatments were effective in reducing the chilling-induced inhibition of radicle elongation (Fig. 6A). As the heat-shock temperature increased from 35 to $50^{\circ} \mathrm{C}$, the time required to induce

Fig. 2. Ranked order on the basis of radicle elongation of germinated okra seeds subjected to the chilling treatments described in Fig. 1.

treatment did not continue the linear decline in percent inhibition to $15 \%$, but almost produced the same inhibition as the $8 \mathrm{~min}$ treatment (30\% vs. $28 \%)$.

The situation was worse for immersed seedlings. If percent inhibition was calculated using the matched nonchilled treatment, then the chilling-induced percent inhibition appeared to be minimized to $38 \%$ by 4 min of heat-shock treatment (Fig. 4 ). This was similar to the $35 \%$ inhibition produced by 8 min of heatshock treatment administered by flotation. However, 4, 8, and 12 min of heat-shock treatment by immersion also reduced radicle elongation of the nonchilled seedlings from 54 to 16, 14, and 16 $\mathrm{mm}$, respectively. This disparity between the responses of floated and immersed seedlings can be seen in a plot of the ranking of radicle length after chilling for seedlings given 4 min immersion and 8 min floatation heat-shock treatments (Fig. 5). Even though both treatments produced similar levels of chilling tolerance when calculated using the same nonchilled, heat-shock-treated seedlings as a control, the seedlings heat shocked by floatation exhibit a wide range of responses. All of the seedlings heat-shocktreated by floatation elongated after chilling, while almost $30 \%$ of the immersed seedlings failed to grow at all.

Cotton. An increase in elongation subsequent to chilling was seen with $45^{\circ} \mathrm{C}$ heat shock treatments applied to radicles prior to chilling (Fig. 4). A 1 min shock reduced chilling-induced inhibition from $70 \%$ to $29 \%$, while 2 min of the heat-shock treatment only reduced it to $47 \%$. Increased durations of heat-shock treatments were detrimental to subsequent elongation. No significant differences were observed among the nonchilled control heat shocked for 1 to 4 min (data not presented).

KENAF. A 4 min heat shock applied to

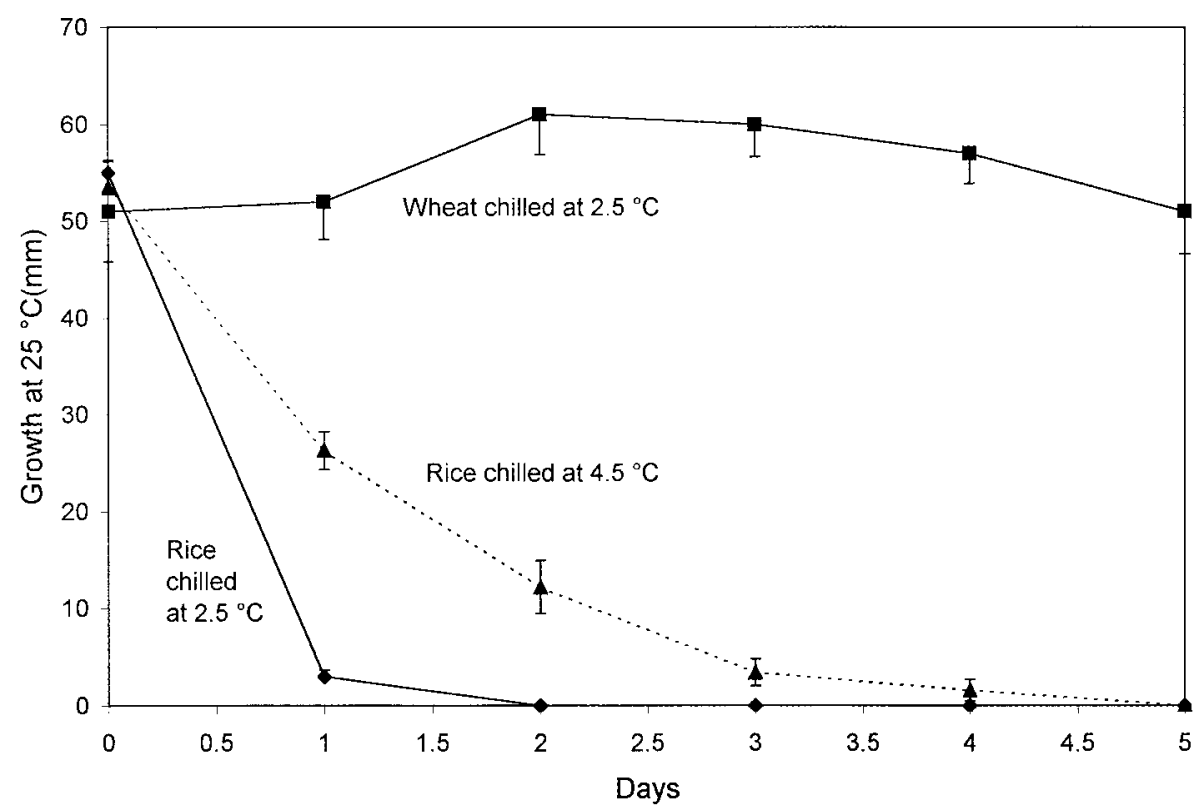

Fig. 3. Chilling at 2.5 or $4.5^{\circ} \mathrm{C}$ for 0 to $5 \mathrm{~d}$ on subsequent radicle elongation of germinated rice and wheat seedlings for $3 \mathrm{~d}$ at $25^{\circ} \mathrm{C}$. Seedlings initially had 10

\pm 1 -mm-long radicles. Vertical bars represent SE $(n=21)$. $1 \mathrm{~min}$ in roughly a linear order protection was given by the optimal time $\times$ temperature combination for each heat-shock treatment, but none of the heat-shock treatments were able to completely protect against chilling. Radicle elongation was still inhibited by $\approx 15 \%$ in the best heatshock treatments.

WhEAT. No increase in elongation after heat shock treatments and chilling was seen with wheat radicles. Treatment with $40{ }^{\circ} \mathrm{C}$ heat shock had no effect on the chilled radicles (Fig 7). Responses of the chilled seeds were similar to those of the nonchilled controls. Treatment with $45^{\circ} \mathrm{C}$ heat shock resulted in decreased elongation with increasing time at $45^{\circ} \mathrm{C}$ for both the chilled and nonchilled wheat radicles. 


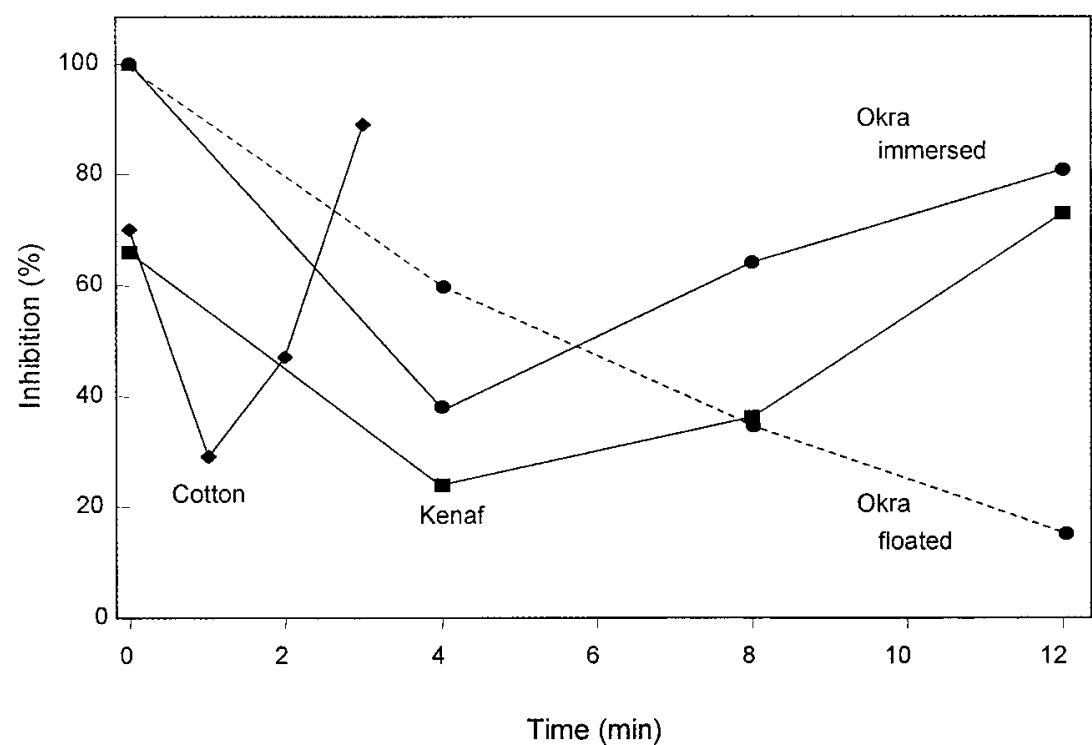

Fig. 4. Heat-shock treatments from 1 to $12 \mathrm{~min}$ at $45^{\circ} \mathrm{C}$ on subsequent inhibition of radicle elongation at $25^{\circ} \mathrm{C}$ for $3 \mathrm{~d}$ caused by chilling seedlings at $2.5^{\circ} \mathrm{C}$ for $3 \mathrm{~d}$. The seedlings initially had $10 \pm 1-\mathrm{mm}$-long radicles. Heat-shock treatments were applied to orka seedlings by immersion or floatation.

\section{Discussion}

While all three malvaceous species were sensitive to chilling injury, their responses to chilling exposure varied. By the third day at $2.5{ }^{\circ} \mathrm{C}$, all three suffered severe reduction in subsequent elongation at $25^{\circ} \mathrm{C}$, however, the point at which serious chilling injury first occurred differed among the crops (Fig. 1). The largest drop in elongation for okra occurred after $1 \mathrm{~d}$ of chilling, after 2 $\mathrm{d}$ for cotton, and after $3 \mathrm{~d}$ for kenaf (Fig. 1). Unlike okra and cotton, which didn't suffer much more damage beyond the third day, kenaf experienced more damage between the third and the fourth day.

Rice, compared to the other species studied, was the most severely affected by exposure to chilling temperatures. Rice seedling radicles suffered a $95 \%$ reduction in elongation after only $1 \mathrm{~d}$ at $2.5^{\circ} \mathrm{C}$, and a $94 \%$ reduction after $3 \mathrm{~d}$ at $4.5^{\circ} \mathrm{C}$ (Fig. 3). Rice also exhibited the least amount of variation in its response to chilling. Intensive breeding of rice may have resulted in a much more uniform genome and therefore a more consistent response to chilling. In contrast to rice, wheat did not exhibit reduced elongation in response to exposure to chilling temperatures, thereby verifying that this species could be used as a chilling tolerant control to examine the effects of heat shock treatments on elongation divorced from its effects of chilling.

In studies conducted by Rab and Saltveit (1996), chilled okra radicles did not grow better when heat shock treatments were applied prior to chilling. They used okra with radicles $5 \mathrm{~mm}$ in length whereas this study used okra with radicles $10 \mathrm{~mm}$ in length. It is known that multiple factors can affect the response of seeds to chilling temperatures, including moisture content of the seeds before imbibition and the period of germination during which chilling temperature exposure occurs (Wolk and Herner, 1982). It is possible that a variety of factors also influence the response of a seed to heat shock treatments followed by chilling exposure.

The three malvaceous species examined in this study all exhibited some degree of heat shockinduced chilling tolerance. All exhibited a beneficial response to $45^{\circ} \mathrm{C}$, although optimal time of heat shock application varied among the crops. Okra responded best to an 8 min heat-shock treatment, while cotton and kenaf responded best to 1 and 4 min heat-shock treatments, respectively. However, the method of heat shock application made a significant difference in how the seedling responded to the treatment. Heat-shock treating okra seedlings by immersing them in $45^{\circ} \mathrm{C}$ water prior to chilling did not result in better subsequent elongation of the radicle than floating the seedlings on the surface of the water in a plastic petri dish. The seedlings that were immersed in $45^{\circ} \mathrm{C}$ attained that temperature within a few seconds, while the seedlings floated on the surface of the water reached $45^{\circ} \mathrm{C}$ after around $60 \mathrm{~s}$ (Rab and Saltveit, 1996). Because the immersed seedlings suffered a much more abrupt temperature change than the ones floated, they therefore experienced the elevated temperature for a greater length of time for each treatment duration. The seedlings may also have become anaerobic for the period of immersion in water, and this may have caused an additional stress that proved detrimental to the seedlings. Since the seedlings that were floated on the surface of the water were in contact with air, anaerobiosis would not have been a problem. When heat-shock treated by immersion, the beneficial effect of heat shock on reducing chilling injury was diminished to insignificance. The inability of heat-shock treatments to induce chilling tolerance in

Fig. 5. Ranked order on the basis of radicle elongation of germinated okra seeds immersed for $4 \mathrm{~min}$ or floated for $8 \mathrm{~min}$ on $45^{\circ} \mathrm{C}$ water followed by chilling for $72 \mathrm{~h}$ at $2.5^{\circ} \mathrm{C}$ and then grown at $25^{\circ} \mathrm{C}$ for $72 \mathrm{~h}$

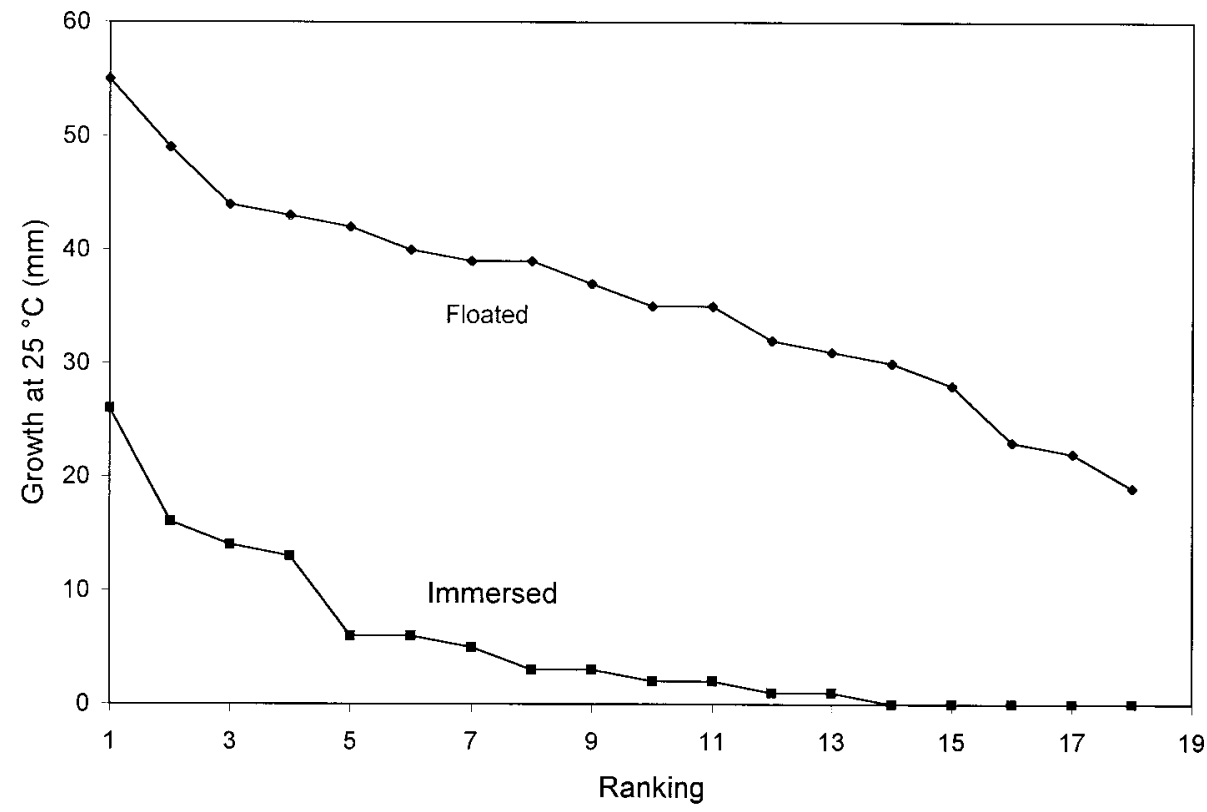



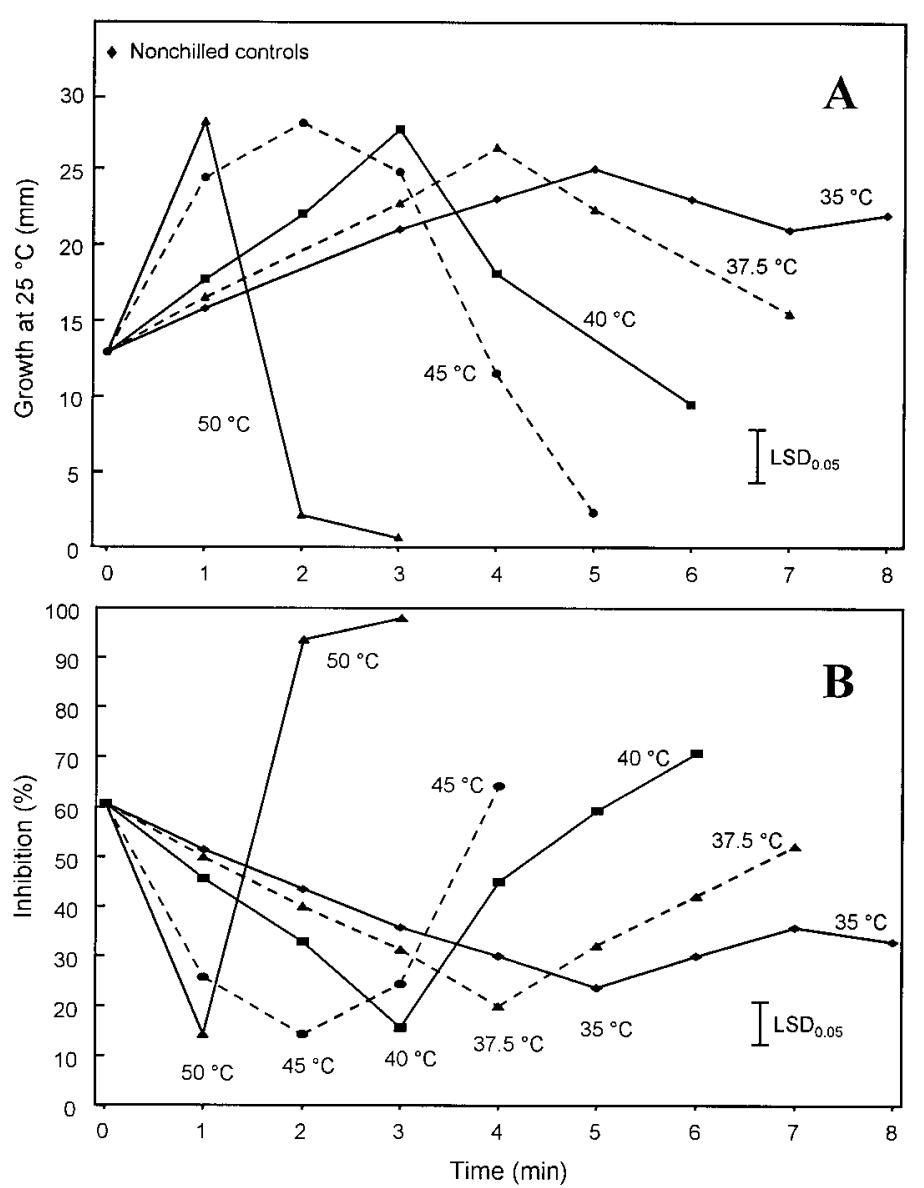

Fig. 6. Heat-shock treatments at 35 to $50{ }^{\circ} \mathrm{C}$ for 1 to $8 \mathrm{~min}$ on (A) subsequent elongation or $(\mathbf{B})$ percent inhibition of rice seedlings radicles initially $10 \pm 1 \mathrm{~mm}$ in length. Seedlings were chilled at $4.5^{\circ} \mathrm{C}$ for $2 \mathrm{~d}$ followed by growth at $25^{\circ} \mathrm{C}$ for $2 \mathrm{~d}$.

some plants could depend on the method of application and on the stringency of the heat-shock and chilling treatments.

When rice seedlings were given a less stringent chilling treatment (i.e., $4.5^{\circ} \mathrm{C}$ for $2 \mathrm{~d}$ ), several time $(1$ to $8 \mathrm{~min}) \times$ temperature $\left(35\right.$ to $\left.50{ }^{\circ} \mathrm{C}\right)$ heat-shock treatment combinations significantly increased chilling tolerance to about the same degree (Fig. 6). As the temperature increased, the exposure time to produce the optimal benefit became steadily shorter. There was insufficient resolution in both the duration of exposure or the heat-shock temperature to characterize accurately the relationship between time and temperature from the raw data. However, when second degree quadratic equations were fitted to the data in Fig. 6 for each temperature, the time of exposure that produced the greatest protection against chilling could be calculated accurately. The $R^{2}$ values were $>0.9$ for all the quadratic equations. The time at each temperature that gave the best protection is given by the second degree quadratic equation: time of heat shock in $\min =(0.0136 \times$ $\left.\mathrm{T}^{2}\right)-(1.419 \times \mathrm{T})+(37.93)$, where $\mathrm{T}=$ heat shock temperature $\left({ }^{\circ} \mathrm{C}\right)$. The equation has an $R^{2}$ of 0.98 , and is only valid over the range 35 to $50{ }^{\circ} \mathrm{C}$. An inspection of the equation shows that the optimal time increases rapidly as the temperature falls below $40{ }^{\circ} \mathrm{C}$, and changes little around $50{ }^{\circ} \mathrm{C}$.

Heat shock treatments did not produce a beneficial effect on the growth of a species not otherwise affected detrimentally by chilling. Elongation of wheat radicles, which was not inhibited by exposure to chilling treatments, was also not aided by heat shock treatments and in fact was harmed by the $45{ }^{\circ} \mathrm{C}$ heat shocks. Wheat was used in this study to determine if heat shock treatments confer a benefit to growth of the radicle beyond an effect conferring chilling tolerance. It appears that the benefits of heat shock treatments to radicles are the result of the alleviation or prevention of a further temperature stress (e.g., heat or chilling stress) and not just an effect on the growth regardless of chilling sensitivity of the tissue.

While some heat-induced chilling tolerance research has been conducted using heat treatments of more than one day (Sabehat et al., 1996), the research reported in this paper agreed with that of Jennings and Saltveit (1994), and Rab and Saltveit (1996) that it is possible to induce chilling tolerance in plant tissue with heat shock treatments of just a few minutes. Prolonged heat treatments may be inducing more changes within the tissue than just induction of the synthesis of heat-shock proteins. In fact, the rate of synthesis and accumulated amount of some hsps decline during exposures to inductive temperatures that last for more than a few hours (Collins et al., 1995; Vierling, E. 1990). Using current technology (i.e., dips in heated water), the large thermal capacity of bulky plant tissue precludes changing the temperature throughout the commodity within a few minutes. However, our research with the seedling radicle model system shows conclusively that the beneficial effect of a heat-shock treatment on increasing chilling tolerance can be induced by exposures as short as a few minutes. If heat shock treatments are ever to be used in practical situations as a method of conferring chilling tolerance to com-

Fig. 7. Heat-shock treatments of 4 to 12 min heat shock at 40 or $45{ }^{\circ} \mathrm{C}$ on subsequent elongation of $10 \pm 1-\mathrm{mm}$ wheat radicles. After the heat shock treatment, the seedlings were either grown for $3 \mathrm{~d}$ at $25^{\circ} \mathrm{C}$ (control), or chilled for $3 \mathrm{~d}$ at $2.5^{\circ} \mathrm{C}$ before growing for $3 \mathrm{~d}$ at $25^{\circ} \mathrm{C}$ (chilled). Vertical bars represent SE $(n=21)$.

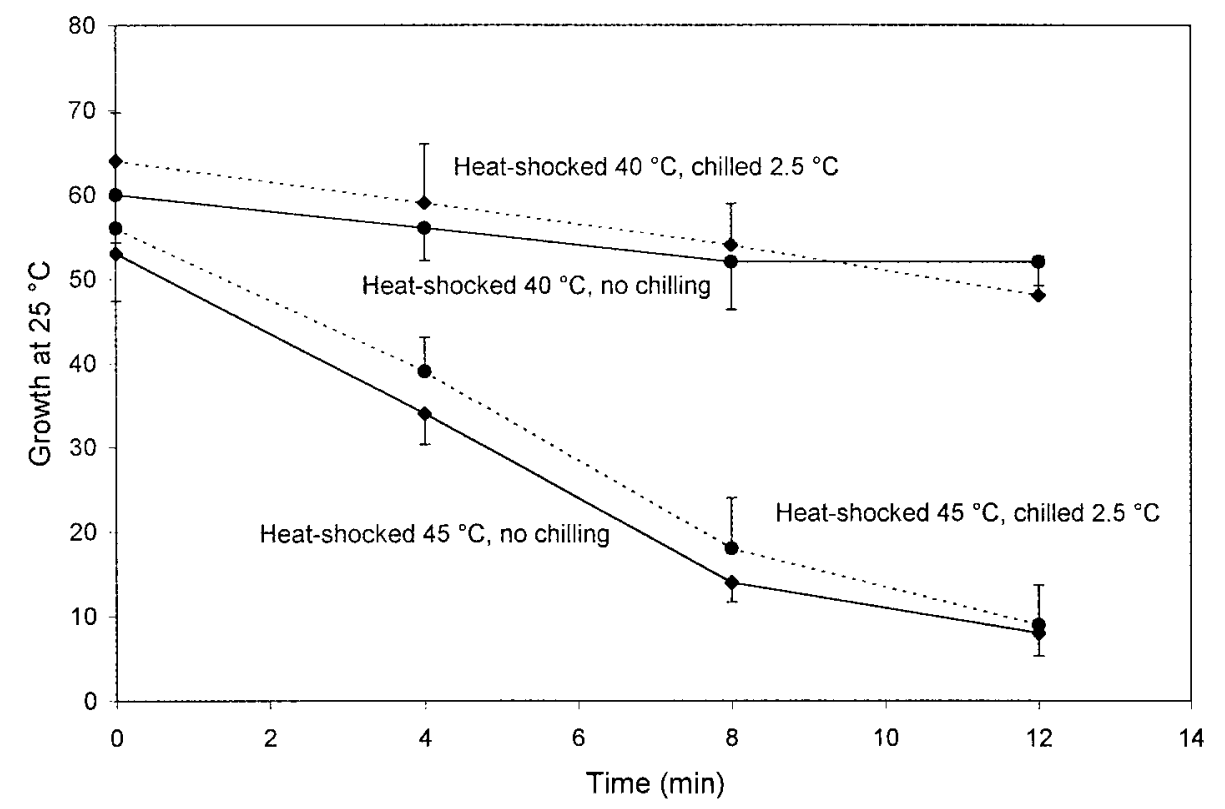


modities such as cucumber and tomato fruit, shorter heat shock treatments $(<15 \mathrm{~min})$ would be of much more use than those lasting several hours or days.

It may be possible to induce some degree of chilling tolerance in all chilling sensitive species with a heat-shock treatment. The ubiquitous response of living organisms to synthesize hsps after a heat shock may have something in common with the ability of heat-shock treatments to confer chilling tolerance to sensitive plant tissues. Although the appearance and disappearance of hsps have been correlated with the induction and loss of chilling tolerance by heat-shock treatments, the mode by which these proteins confer chilling tolerance is not known. It is possible that heat shocks induce tolerance by another mechanism than the induced synthesis of shock proteins.

\section{Literature cited}

Collins, G.G., X.L. Nie, and M.E. Saltveit. 1993. Heat shock increases chilling tolerance of mung bean hypocotyl tissue. Physiol. Plant. 89:117-124.

Collins, G.G., X.L. Nie, and M.E. Saltveit. 1995. Heat shock proteins and chilling sensitivity of mung bean hypocotyls. J. Expt. Bot. 46:795-802.

Jennings, P. and M.E. Saltveit. 1994. Temperature effects on imbibition and germination of cucumber (Cucumis sativus) seeds. J. Amer. Soc. Hort. Sci. 119:464-467.

Lyons, J.M. 1973. Chilling injury in plants. Annu. Rev. Plant Physiol.
24:445-466.

Lyons, J.M. and J.K. Raison. 1970. Oxidative activity of mitochondria isolated from plant tissues sensitive and resistant to chilling injury. Plant Physiol. 45:386-389.

Nishida, I. and N. Murata. 1996. Chilling sensitivity in plants and cyanobacteria: The crucial contribution of membrane lipids. Annu. Rev. Plant Physiol. Plant Mol. Biol. 47:541-568.

Rab, A. and M.E. Saltveit. 1996. Sensitivity of seedling radicles to chilling and heat-shock-induced chilling tolerance. J. Amer. Soc. Hort. Sci. 121:711-715.

Sabehat, A., D. Weiss, and S. Lurie. 1996. The correlation between heatshock protein accumulation and persistence and chilling tolerance in tomato fruit. Plant Physiol. 110:531-537.

Saltveit, M.E. 1991. Prior temperature exposure affects subsequent chilling sensitivity. Physiol. Plant. 82:529-536.

Saltveit, M.E. 1999. Discovery of chilling injury, p. 423-448. In: S.D. Kung and S.F. Yang (eds.). Discoveries in plant biology. vol. 3. World Scientific Publ. Co., Singapore.

Saltveit, M.E. and R.M. Cabrera. 1987. Tomato fruit temperature before chilling influences ripening after chilling. HortScience 22:452-454.

Saltveit, M.E. and L.L. Morris. 1990. Overview on chilling injury of horticultural crops, p. 3-15. In: C.Y. Wang (ed.). Chilling injury of horticultural crops. CRC Press, Boca Raton, Fla.

Vierling, E. 1990. The role of heat-shock proteins in plants. Annu. Rev. Plant Physiol. Plant Mol. Biol. 42:579-620.

Wolk, W.D. and R.C. Herner. 1982. Chilling injury of germinating seeds and seedlings. HortScience 17:169-173. 